This item was submitted to Loughborough's Research Repository by the author.

Items in Figshare are protected by copyright, with all rights reserved, unless otherwise indicated.

\title{
Extreme right-wing populism in Europe: revisiting a reified association
}

PLEASE CITE THE PUBLISHED VERSION

https://doi.org/10.1080/17405904.2017.1309325

PUBLISHER

(C) Taylor \& Francis

VERSION

AM (Accepted Manuscript)

\section{PUBLISHER STATEMENT}

This work is made available according to the conditions of the Creative Commons Attribution-NonCommercialNoDerivatives 4.0 International (CC BY-NC-ND 4.0) licence. Full details of this licence are available at: https://creativecommons.org/licenses/by-nc-nd/4.0/

\section{LICENCE}

CC BY-NC-ND 4.0

\section{REPOSITORY RECORD}

Stavrakakis, Yannis, Giorgos Katsampekis, Nikos Nikisianis, Alexandros Kioupkiolis, and Thomas Siomos. 2019. "Extreme Right-wing Populism in Europe: Revisiting a Reified Association". figshare.

https://hdl.handle.net/2134/31990. 


\title{
Title: EXTREME RIGHT-WING POPULISM IN EUROPE
}

\author{
Subtitle: Revisiting a Reified Association
}

\section{Authors:}

1. Yannis Stavrakakis (corresponding author)

Professor, School of Political Sciences, Aristotle University of Thessaloniki

Principal Investigator, POPULISMUS

Postal address: 46 Egnatia, Thessaloniki, 54625, Greece

e-mail: yanstavr@yahoo.co.uk

Telephone number: 00306974619728

2. Giorgos Katsambekis

$\mathrm{PhD}$ candidate, School of Political Sciences, Aristotle University of Thessaloniki

Doctoral researcher, POPULISMUS

Postal address: School of Political Sciences, Basement floor, Faculty of Economics and Political Sciences, Aristotle University Campus, Thessaloniki, 54124, Greece e-mail: giorgos_bek@hotmail.com

\section{Nikos Nikisianis}

Post-doctoral researcher, School of Political Sciences, Aristotle University of Thessaloniki

Post-doctoral researcher, POPULISMUS

Postal address: School of Political Sciences, Basement floor, Faculty of Economics and Political Sciences, Aristotle University Campus, Thessaloniki, 54124, Greece e-mail: nnikisia@gmail.com

\section{Alexandros Kioupkiolis}

Assistant Professor, School of Political Sciences, Aristotle University of Thessaloniki Researcher, POPULISMUS

Postal address: 46 Egnatia, Thessaloniki, 54625, Greece

e-mail: alkioup@yahoo.gr

\section{Thomas Siomos}

PhD candidate, School of Political Sciences, Aristotle University of Thessaloniki Doctoral researcher, POPULISMUS

Postal address: School of Political Sciences, Basement floor, Faculty of Economics and Political Sciences, Aristotle University Campus, Thessaloniki, 54124, Greece e-mail: siomos.thomas@gmail.com

\begin{abstract}
Revisiting the trend of identifying populism with extreme right parties, in this paper we aim to problematize such associations within the context of today's Europe. Drawing on examples from relevant parties in France and the Netherlands, and
\end{abstract}


applying a discourse-theoretical methodology, we test the hypothesis that such parties are better categorized primarily as nationalist and only secondarily - and reluctantly as 'populist'. Our hypothesis follows the remarks of scholars who have stressed that the central theme in the discourse of such parties is not the staging of an antagonism between a 'people' and an 'elite', but rather the opposition of an ethnic community with its alleged dangerous 'others'. In this context, we propose a discursive methodology able to differentiate between 'populist' and 'nationalist' (xenophobic, racist, etc.) discourses by locating the core signifiers in each discourse in relation to peripheral ones, as well as by clarifying the nature of the axial antagonisms put forth.

\section{Keywords}

Populism, extreme right, Europe, discourse, Essex School, France, Netherlands

\section{Introduction}

During the last two decades, and especially within the past ten years, the term 'populism' has become one of the most common but also vague buzzwords among European political and social scientists. Following the impressive rise of Jean-Marie Le Pen and the National Front in France during the late 1980s and 1990s, and then of other emblematic figures of the radical Right, like Jörg Haider in Austria, scholars have shown a great deal of interest in understanding and analysing such formations. They have also debated extensively their relation to democratic and representative institutions as well as their potential for further electoral gains with reference to their 'populist', 'national-populist' or 'exclusivist populist' character. But ever since the 
introduction of the category of 'populism' as a basic descriptive and analytical tool in accounting for such formations, very few have ever re-examined in a consistent and systematic way the very applicability of the term to this type of political forces, which sometimes includes even extremist, fascist or neo-Nazi ones.

As a result, we often see 'populism' being used as synonymous to right-wing populism or to the populist extreme right, or even to the extremist neo-Nazi right, a reified association that ignores both the global diversity of populist phenomena (which, in Latin America, for example, are mostly located on the Left) as well as the increasingly diversified picture within Europe itself. Indeed the dynamic emergence of populist parties that belong to the Left or even the radical Left, like SYRIZA in Greece or PODEMOS in Spain, or others that are rather hard to locate on the political spectrum, like Beppe Grillo's Five Star Movement in Italy, seems to have radically altered the European picture.

Challenging this arguably euro-centric trend, we purport to revisit and problematize the very applicability of the category of 'populism' to far right, radical right or extreme right parties within Europe. Focusing on examples from relevant parties in two key-countries (France and the Netherlands), and by applying a discourse-theoretical methodology inspired by the so-called 'Essex School' - drawing on and further operationalizing the theoretical input of Ernesto Laclau (1977, 1980, 2005) -, we will put forward the hypothesis that such parties are better categorized as nationalist, xenophobic, maybe even elitist, and only secondarily - if at all - as 'populist'. The formulation of this hypothesis has also been inspired by recent remarks by a series of scholars (see Di Tella, 1997; Ignazi, 2006; Mudde 2007; Caiani and Della Porta, 2011; Wodak 2014, 2015) who have stressed that the central characteristic in the discourse of such parties is an emphasis on the protection of the 
nation, of the native people and culture, against the enemies of the nation and its dangerous 'others': immigrants, foreigners or some other perceived external threat. If this is the case, their references to the 'people' may have to be seen as rhetorical vehicles of nationalism, relegating a typically populist antagonism towards the elite to the periphery of their discursive articulation. In other words, our main claim is that in various discourses that are 'by default' considered to be populist, what occupies the limelight is not an antagonism between a 'people' and an 'establishment' or a 'power bloc', as is the case typically with populism. It is rather the opposition between a homogenous ethnic community and its ethno-cultural 'other', something that indicates a narrative highlighting 'the centrality and supremacy of the nation and nationalism', resembling a nationalist myth par excellence (see Hainsworth, 2008, pp. 77-78; Minkenberg, 2002, p. 337).

In this context, we will propose a rigorous discursive methodology that may be able to distinguish 'populist' from 'nationalist' (xenophobic, racist, etc.) discourses by differentially identifying the core signifiers in every discourse in relation to the peripheral ones and by clarifying the way in which the antagonistic divide is constructed and signified in each discursive architectonics.

\section{Populism and the Extreme-Right}

In a recently published monograph, Stijn van Kessel acknowledges that in 'the European context, populism is habitually associated with xenophobic politics and parties of the extreme or radical right (and therefore considered to be dangerous)'. This, he continues, 'is not surprising, since populism in Western Europe has often been expressed by parties characterised by a nationalist and culturally conservative ideology, and hostility towards immigration and multiculturalism. The European 
academic literature has therefore also mainly considered populism as an element of "the right", (van Kessel, 2015, p. 2). Van Kessel is among those that rightly acknowledge that populism 'is not necessarily related to xenophobic politics or to any of the other properties of the radical right' (van Kessel, 2015, p. 2), and that it can be found in very different types of parties, ranging from the extreme right to the extreme left and also encompassing the centre. Daniele Albertazzi and Duncan McDonnell have also acknowledged that the "insistence on making "populist" and "extreme right" synonymous or lumping all populists under the "radical Right populist" banner for ease of comparison [...] is detrimental to our understanding both of specific mislabelled parties [...] and populism itself' (Albertazzi and McDonnell, 2008, p. 4). Nevertheless, one still encounters reductionist approaches that tend to exclusively associate populism with the right or the extreme-right, in one way or another. Surprisingly enough, a recent such example comes from Albertazzi and McDonnell's latest monograph, entitled Populists in Power (2015). Ironically, while the title of the book refers to 'populists' in general, its content only encompasses right and extreme right-wing parties, illustrating the gradual reification of the association between populism and the extreme right in the relevant debates.

In the work of Jagers and Walgrave it is only when an exclusivist signification of 'the people' is present that a political party can qualify as a 'full instance' of populism. In their own words, '[t]he thick definition $[\ldots]$ consists of a combination of the three elements and states that populism refers to the people, vents antiestablishment ideas and simultaneously excludes certain population categories' (Jagers and Walgrave, 2007, p. 322). In this context, it does not come as a surprise that in their oft-cited paper they conclude that the nationalist, xenophobic and racist Vlaams Blok constitutes a case of 'thick' or 'full' populism par excellence, with its 
exclusivist and extreme nationalist discourse playing a key-role in understanding it as such: 'it is the party's extreme nationalism - the party wants to break up the Belgian state and set up a separate Flemish state - that explains its populism' (Jagers and Walgrave, 2007, p. 336). Some short of strong enmity against internal enemies, enemies 'within the people,' 'scapegoats' to be eradicated, 'removed from the territory of the people' (Jagers and Walgrave, 2007, p. 324), becomes here a necessary precondition, a qualifier for populism.

Last but not least, a similar association can be found in a recent Green European Foundation publication entitled Populism in Europe (Meijers, 2011). Thus, while the title refers to European populism in general, the actual content of the book is dedicated almost exclusively to right-wing, nationalist and xenophobic political parties and the ways to deal with them, effectively equating the extreme right with populism. It is quite telling that the editor of this publication, Erica Meijers, suggests that the populists' 'proclaimed aim is to protect the identity of the "Christian Western civilisation" by closing borders and attacking cultural, ethnic and religious minorities' and that they "create an unbridgeable gap between the "bad" elite, the "good" people and the "other" (usually minority groups)' (Meijers, 2011, p. 5). Furthermore, Meijers suggests that '[p]opulists use the term "people" in an absolute and exclusive way' (Meijers, 2011, pp. 11-12), while, at the same time, they are 'harping on the old "mechanisms of exclusion and xenophobic nationalism"' (Meijers, 2011, pp. 78). No reasons as to why such characteristics have to apply to populism tout court and are not indicative of something more accurately described as xenophobic, extreme right nationalism are offered. Likewise, no clear rationale is usually provided at the conceptual level by all those choosing to describe the Greek Golden Dawn, a neoNazi para-military organization, as populist (Anastasakis, 2013; Halikiopoulou and 
Vasilopoulou, 2013). Such approaches seem to ignore or overlook Cas Mudde's now classic - monograph on the populist radical right, where he explicitly stresses that 'nativism, not populism, is the ultimate core feature of the ideology of this party family' (Mudde, 2007, p. 26). In fact, populism only comes third, as an ideological feature that defines such parties, after nativism and authoritarianism (Mudde, 2007, pp. 22-23).

In an effort to draw the line between outright nationalist, xenophobic or extremist/neo-Nazi parties and populism, and to avoid the reification of a potentially problematic association, we employ in this paper a discursive approach based on the two minimal criteria emanating from the work of Ernesto Laclau and the so-called 'Essex School' (Howarth \& Stavrakakis 2000; Phillips \& Jorgensen 2002; Townshend 2003, 2004). These criteria are also relevant to - if not reflected on - the currently emerging academic consensus on a 'minimal' definition of populism (see van Kessel, 2015; Mudde and Rovira Kaltwasser, 2012; Canovan, 1999; also see Stavrakakis and Katsambekis, 2014, pp. 121-124). We then apply these criteria in 'classic', widely debated cases of the populist right/extreme-right in France (Front National / FN) and the Netherlands (Partij voor de Vrijheid / PVV) in order to illuminate the exact relationship between populism, nationalism and xenophobia. Last but not least, very brief comparisons are drawn with the left counterparts of these parties in order to stress the variability of significations of 'the people' but also of social antagonisms in alleged populist discourses of the right and left and to highlight the shifting picture in the European context.

\section{Using Minimal Criteria to Analyse Populism: An Essex School Approach}


Despite the various conceptualizations of populism and the differing analytical models that have been put forth during the past few years, there is now a clearly emerging consensus on its core (or 'minimal') characteristics. This broad consensus around so-called discursive or ideological/ideational approaches (see de la Torre, 2015; Mudde and Rovira Kaltwasser, 2012; Panizza, 2005) seems to validate the two 'operational criteria' put forward by discursive scholars (Laclau, 2005; Stavrakakis, 2004). At its most basic level, an Essex-School-oriented approach to populism is premised on establishing whether a given discursive practice under examination is, first, articulated around the nodal point 'the people' or other non-populist nodal points (nation, class, etc.), ${ }^{1}$ and, second, to what extent the representation of society it offers is a predominantly antagonistic one, dividing the social field between two antagonistic camps: 'the people' (the underdog, the non-privileged, the 'many', and so on), on the one side, and the 'elite' (the establishment, the power bloc, and so on), on the other. This is indeed how Laclau's logic of equivalence manifests itself: through the production of populist (discursive) chains of equivalence, a term signifying the articulatory mechanism through which different identities and demands become 'equivalent' in their opposition to a common 'enemy' (Laclau, 2005, pp. 77-83). When these two discursive conditions are in place at the same time, it is assumed that it is rather safe to identify a party or a movement as 'populist' (Stavrakakis and Katsambekis, 2014).

Although emanating from a very different intellectual tradition, this definition, based on minimal criteria and already employed in a number of empirical analyses (see, for example Stavrakakis, 2003, 2005; Stavrakakis and Katsambekis, 2014; Katsambekis, 2016), shares a lot with the ground-breaking work of scholars who have stressed the merits of Sartorian minimal definitions when it comes to empirical 
comparative research (van Kessel, 2015; Rooduijn, 2014; Mudde and Rovira Kaltwasser, 2012). At the same time, it may avoid certain shortcomings present in these definitions. Despite the significant steps taken by such scholars, it seems difficult to register the importance they place on relating or even equating populism with a strictly moralistic view (developed along the good/evil and pure/corrupt axes) and a homogenizing construction of the people. When given at the level of a definition, such assumptions tend to produce a latent analytical and normative bias, thus blurring the specificities of the cases under focus, much more than facilitating their clarification. Why, in other words, should one exclusively associate a moralistic framing of antagonistic divides and a homogenizing view of political subjectivity with populism? Could it be that such assumptions stem from a latent association of populism with the extreme or radical right, where understanding the people as a homogenous nation is more common, as well as understanding the enemies of the people-as-nation as fundamentally evil? After all, one is to find the first formulation of such a moralistic 'minimal' definition on a classic monograph dedicated to the 'radical right' (Mudde, 2007).

Furthermore, it has been substantiated that in many cases such claims regarding moralism and homogeneity do not hold true (see Stavrakakis and Katsambekis, 2014; Katsambekis, 2016), to the extent that a populist discourse can indeed construct forms of popular unity (not homogeneity) without effectively homogenizing the popular subject and without necessarily stigmatizing the political opponent in moralistic terms, but in straightforward political ones. In addition, although traced in certain populist phenomena (for example, Chavismo), attributions of purity and moralistic idealization - probably remnants of a religious imagery reemerging in secular form - can be also encountered in a variety of discourses 
articulated around very different nodal points. De la Torre is right to point out that such narratives of redemption epitomize 'the saga of the people, the proletariat, the indigenous, or the nation' (De la Torre, 2015, p. 10). It is thus difficult to see how this criterion could help in the differential identification of populist discourses.

Last but not least, for many influential critical political theorists, the turn to moralistic discourse, 'the displacement of politics by morality', constitutes a defining characteristic of anti-populist consensual politics positioned beyond left and right; here moral condemnation is revealed as a neoliberal strategy of exorcising the populist challenge (Mouffe, 2002, pp. 1, 14). If this is indeed the case, then, once more, this criterion cannot form part of a minimal definition of populism. Thus, in order to be in a better position to deal with the vast plurality of populist hybrids and to identify the characteristics peculiar to them, in order to arrive at a truly minimal and operational definition of populism, one would have to bracket the significance of moral investment and idealization. By following this course, by 'purifying' the definitions put forward by the 'new mainstream' in populism studies, we will quickly realize that we are left with a definition very close to the one given by Laclau roughly forty years ago and further developed since then (Laclau, 1977, pp. 172-173; 1980; 2005). Such a definition understands populism as a formal political and discursive logic, a performative process which constructs and represents society as ultimately divided between two groups, 'the people' and 'the elite', and which argues that politics should be an expression of the will of the people. ${ }^{2}$ It is crucial to stress here that while this conceptualization also bears similarities with a body of work that understands populism more as a political communication style (e.g. Moffitt 2016; Jagers \& Walgrave, 2007), we prefer the term 'discourse' or 'discursive logic,' since discourse constitutes the core material of analysis and should not be treated as 
something secondary or superficial - an unavoidable connotation of 'style'. Moreover, by sticking to the notion of discourse, our analysis can employ a widely tested, elaborate and solid methodology within the constantly evolving field of discourse studies (Howarth, Norval \& Stavrakakis, 2000; Angermuller, 2014; Angermuller, Maingueneau \& Wodak 2014). After all, even researchers that prefer to understand populism as 'style', most often end up performing a discourse analysis of sorts when conducting empirical research. For example, Jagers and Walgrave end up describing their analytical effort as 'comparative discourse analysis' (Jagers \& Walgrave, 2007, p. 319).

\section{Research Design and Country/Case Selections}

With these theoretical/methodological priorities in mind, we can now proceed with briefly examining the particular logics that govern the discourse of specific parties regarded as belonging to the populist extreme right or populist right; the core signifiers around which their discourse is articulated, as well as the ways in which social antagonisms are framed and signified. Our aim is to show that by utilizing a formal discursive methodology premised on minimal criteria one can hope to clarify the role of populist signifiers and logics in a given discourse, while at the same time draw meaningful comparisons with diverging cases. Our minimal criteria here can be reformulated as abstract questions: (1) Is the 'people' the central reference of a given discourse? (2) Is this people opposed to an established power bloc? In this sense, the emphasis that we put here on discourse leads us, as a first step, to investigate the exact position of populist signifiers: i.e. where do we locate the reference to 'the people' in an extreme-right populist discourse? Is it indeed a nodal point, placed at the very core of its articulation, or is it located in the periphery? If at the core of these discourses we 
find an ethnic community (conceptualized either in political or in ethnic/racial terms) and if the enemy against which they mobilize is, once more, illustrated in nationalist terms, shouldn't we better understand these discourses as predominantly nationalist?

However, to the extent that in extreme right discourses one expects to find numerous references to both 'people' and 'nation', one would need to take a second step in order to strengthen the applicability of the two minimal criteria (identifying both the central position of the 'people' in discursive architectonics as well as the dichotomization of the socio-political terrain between a popular and an elite camp) by inquiring into how exactly, in each case, the people and the elite are constructed, articulated and illustrated (Who is the people? Who is the elite?). From a formal, discursive perspective prioritizing differential identification, the hypothesis here would be that in populist discourses proper, apart from being located at the core of the discursive articulation, 'the people' would function as an empty signifier, as a signifier without signified, so to speak (Laclau 2005, pp. 69-72, 161-163). In contradistinction, discourses not qualifying as predominantly populist would employ the signifier the 'people' either by locating it at the periphery of their chain of signification or, when it is given a more central place, by moderating its emptiness, referring it back to 'race' or 'nation', discursive units that in extreme right discourse often function as naturalized, original (mythical) points of reference, as 'transcendental signifieds' attempting to fix signification once and for all (Derrida 2005: 354) - and thus forestalling the fluidity accounting for the hegemonic appeal of paradigmatic populist articulations.

An illuminating analogy can be drawn here from the left of the political spectrum, in order to register the problems with understanding every call upon the people as ultimately and equally populist. We know that in communist discourses - as 
in the case of the Greek Communist Party (KKE), for example - one finds a central reference to 'the people' too. However, in this case, the central position of this signifier does not suffice to characterize a party like the KKE as 'populist'. For if we proceed with an in-depth analysis of such discourses we will find that 'the people' refers back to another signifier - the 'working class' - which often functions as an undisputed referent guaranteed by the naturalized objectivity of class divisions. In other words, 'the people' is not an empty signifier able to integrate heterogeneous identities and demands in a broader chain of equivalences, nor do we find a sharp dividing line pitting the vast majority of society against an established 'elite'. In such a context, all social antagonisms are constructed and represented as elements of an inevitable 'class struggle', which underlies society on every level, often fragmenting popular fronts into partial class interests and thus leaving little or no place for the creative and innovative articulations marking populist discourses.

Moving on from our research questions, findings presented here are drawn from research conducted within the framework of the POPULISMUS project, which entailed a thorough literature review, a series of semi-structured interviews with experts and politicians in many European and Latin American countries, as well as the collection and discursive analysis of party documents (manifestos, speeches, articles, etc.). ${ }^{3}$ Due to space limitations we can only present a small fragment of these findings, indeed in summary form, which we consider crucial for the advance and development of the debate on the extreme right and populism in Europe. We chose to focus on two specific countries, France and the Netherlands, which occupy a prominent place in the ingoing debate. In the case of France, we focus on the FN, which can be regarded as the 'cradle' of contemporary extreme right-wing populism in Europe, with the Le Pens being, perhaps, the most well-known political figures of 
this particular party family. The Netherlands were considered equally important due to the significant dynamic of Geert Wilders and his party (Party for Freedom / PVV), as well as his role in the formation of a pan-European alliance along with FN leader Marine Le Pen.

\section{Positioning 'the People', Signifying Antagonisms}

We will now proceed with brief overviews of our cases, highlighting their specific characteristics in light of the minimal criteria approach presented and operationalized above. First, we are interested in clarifying the position of 'the people' as well as its relation with other core signifiers representing political subjectivity in every case. More specifically, we aim to clarify if it is placed at the core of a given articulation, functioning as a populist empty signifier purporting to articulate an expanding plurality of social demands, or at the periphery in both its senses: in terms of architectonics (indicating a marginal and secondary position within a given discursive articulation) or in terms of functioning as a mere rhetorical vehicle of a prioritized and often naturalized nationalist signification. Our inquiry on this level could also be formulated in terms of interrogating the type of political subjectivity constructed through a given interpellation of 'the people'. Second, we focus on the antagonistic schemas that each discourse is putting forward, in order to establish whether they are compatible with a formal populist logic or not. Our aim here is to clarify the specific characteristics of a given pattern of articulation in terms of constructing populist (or non-populist) polarities.

Geert Wilders and the PVV in the Netherlands: Defending 'Henk and Ingrid' against Islamisation 
The 'spectre of populism' as well as that of anti-islamism enters the Netherlands in the early 2000s with Pim Fortuyn and his party, the LPF (List Pim Fortuyn / Lijst Pim Fortuyn) which has been classified as right or extreme-right by several commentators (see Koopmans and Muis, 2009). Fortuyn shook the political scene with his flamboyant life-style, anti-establishment positions and strong anti-islamist rhetoric, causing the media and his opponents to immediately react, recognizing him as a 'far-right Dutch maverick' with 'anti-Muslim views' (BBC, 2002), indeed as 'the new dynamic face of the Right in Europe' (Osborn, 2002). Fortuyn presented a peculiar mix of characteristics and ideas, yet associations with the extreme right occurred after he declared Islam to be a 'backward' culture in 2002 (Andeweg and Irwin, 2005, p. 16). Some years earlier he had also authored a book with the characteristic title Against the Islamisation of our Culture: Dutch Identity as a Foundation (1997). To be sure, Fortuyn never called for the ousting of every Muslim immigrant, but rather for a deeper integration of such populations within Dutch society. Thus his blend of nationalism and anti-islamism has been regarded as rather 'mild' and perhaps 'civic', since it avoided ethnocentric and organismic conceptions of the nation and could thus be combined with liberal values (Akkerman, 2005). Hence, what defined Fortuyn's party was an anti-establishment positioning embedded in a vocal anti-islamist and anti-immigration rhetoric, as well as an opposition to multiculturalism, all with the aim of protecting and preserving the native culture and values; a rhetorical blend that broke many taboos within the Dutch society and political scene.

In an unexpected twist of events, Fortuyn was assassinated in 2002, only a few days before the elections. His party, the LPF did spectacularly well, but nevertheless soon collapsed in his felt absence. Fortuyn's death and the LPF's downfall 
immediately created a sense of vacuum in the Dutch political scene (Akkerman, 2005, p. 351), since it had become clear that social anxieties and fears against immigration and Islam were in need of political representation. Thus, it did not take long for another politician to build his campaign based on opposing the alleged danger of 'Islamisation' and of 'criminal immigrants' within Dutch society. This politician was Geert Wilders, a former member and MP for VVD already from 1998, that had voiced his concerns regarding the 'danger of Islam' long before he founded his own party, the PVV (Vossen, 2011, p. 181). Wilders had become widely known after opposing plans for the accession of Turkey to the European Union, which resulted in his breaking with the VVD (van Kessel, 2015, p. 104; Lucardie and Voerman, 2012, pp. 153-154). Soon after leaving the VVD he would take an active role in the NO campaign against the European constitution in the Dutch referendum of 2005 (de Lange and Art, 2011, p. 1235). With such positions he soon acquired the profile of a vocal anti-establishment politician who is not afraid to cross the line of political correctness. In 2006, he founded the PVV, of which he remains the only member until today as well as its undisputed leader. This step indicated, for Koen Vossen, the passage of Wilders from neo-conservatism to 'national populism' (Vossen, 2011, p. 184). No doubt, from the very beginning of this new phase in his career, Wilders identifies one ultimate enemy in his discourse: Islam, which is perceived both as a threat to the Dutch culture and way of life, but as a serious security threat too. Indeed, Wilders' islamophobia is 'based on apocalyptic conspiracy theories on the coming Islamification of Europe' (Vossen, 2011, p. 184) and is over-determining almost every aspect of his discourse and ideology.

It is noteworthy that in Vossen's enumeration of Wilder's characteristics, populism comes only fourth. What is more, Vossen himself immediately links 
Wilders' alleged populism to his islamophobia. In his own words, the latter refers 'to the common people who are fed up with criminality, Islamisation and politics in general and who demand immediate action' (Vossen, 2011, p. 185). Indeed, if one focuses on Wilders' attacks against the 'establishment' and in the ways in which he interpellates 'the people', he or she will immediately realize that there is almost always a straight link to the danger of 'islamisation', for which the established parties are doing nothing, while it is always only the native Dutch people that need to be protected. Thus, even if there are populist elements in Wilders' discourse (and indeed there are), these are better understood as strategic 'amplifiers' of his anti-Islam and anti-immigrant message. Take, for example, how one of the main antagonistic (Us vs. Them) schemas is framed in his discourse: when he speaks about 'the people', he chooses to speak about 'Henk and Ingrid', which are (probably) the most common names for native Dutch people. The figures opposite Henk and Ingrid, in Wilders' discourse - that, as signifiers, operate as antithetical equivalents to the Dutch nation -, are 'Mohammed and Fatima', two of the most well-known names of Muslim people (see Wilders, 2008; Dutch News, 2010).

Another example that offers a very graphic illustration of how Wilders is framing socio-political antagonisms in his discourse comes from the recent electoral campaign for the 2012 elections, in which the PVV chose to oppose Europe. The title of the electoral manifesto of the PVV was: 'Their Brussels, our Netherlands' (PVV, 2012). And while this slogan can be considered as an attack against Europe's antidemocratic bureaucratization and its alienated 'elites' (see van Kessel, 2014), it is very clear that 'us' versus 'them' refers primarily to a battle between 'our nation' ('our Netherlands') and an external organization, the EU, which is often presented as a monstrous 'super-state' (see Wilders, 2011). Moreover, when we dig a bit deeper to 
see what the main problem with Europe is, we will again find an islamic threat to the Dutch nation (and to Western states in general), framed in an outright conspiracytheory manner:

The EU's aim [...] seems to be to destroy the old sovereign nations and replace them by new provincial identities, which are all clones of each other. Britanistan will not differ from Netherlandistan, nor Germanistan from Italiastan, or any other province of the European superstate in the making (Wilders, 2011; emphasis added).

Tellingly enough, when very recently Wilders co-hosted a news conference with Marine Le Pen to present their newly established bloc in the European Parliament, he stressed that their ultimate aim was to 'fight the "Islamisation" of Europe' (Saeedy, 2015). In this context, Wilders does not hesitate to often talk about a war-like situation between his notions of the West and Islam (Wilders, 2014a; 2014b; 2015b). Thus it does not come as a surprise that the clear solution that he ends up proposing is the return to the nation and to the most classic sense of nationalism framed in essentialist (and quasi-metaphysical) terms: 'The peoples of the free world will only be able to fight back against Islam if they can rally around a flag with which they can identify. This flag, symbolizing pre-political loyalty, can only be the flag of our nation' (Wilders, 2011). In this sense, the people are constructed as a strictly ethnic people, and can be united only around a symbol which exerts some sort of prepolitical and thus unmediated loyalty to the nation, which needs to be empowered against the 'multiculturalists' that, according to Wilders, 'aim to destroy it' (Wilders, 2011).

In this sense the people becomes completely indistinguishable from the nation. Indeed the nation clearly emerges as the transcendental signified of the 'people' in the 
most naturalized way, with Islam being its constitutive outside. As Gerrit Voerman notes,

Immigrants are clearly excluded from Geert Wilders' vision of the people. [...] So, Wilders [compared to Fortuyn] is going one step further, by excluding immigrants even if they live in the Netherlands or are Dutch citizens and have Dutch nationality. They still are not part of the people. They are Muslims, and Muslims do not belong to the people. [...] This is a very nationalist approach to the people. So, Wilders is very exclusionist (Gerrit Voerman, interview, Groningen, 26 September 2014).

We have registered similar remarks from the majority of experts we have interviewed in the Netherlands during our field research, which highlight both the exclusivist nature of Wilders' discourse, but also its primarily nationalist or nativist character. ${ }^{4}$ One characteristic such remark comes from Paul Lucardie, who stresses that 'the PVV is more extreme, in that for Wilders this anti-Muslim attitude is really at the core [...] In that sense $[\ldots]$, for him anti-Islamism is almost an ideology in itself $[\ldots]$ indeed, more important than populism'. Interestingly, Lucardie then adds that this might be true for many other so-called 'populist' parties in Europe, 'especially for the rightwing populists', since 'for most of them populism tends to be subordinate to nationalism [...]' (Paul Lucardie, interview, Groningen, 26 September 2014).

Concluding our examination of Wilder's discourse, it is useful to contrast it to a competing - and indeed populist - discourse located on the left of the political spectrum, in particular that of the Dutch Socialist Party (SP) (see Voerman, 2008). As Voerman notes, 'in Wilders view the people is defined by nationalist or ethnic criteria. With the SP, this is not the case. The SP talks about the "common man", but this man can be an immigrant. They do not exclude immigrants from being a common 
man' (Gerrit Voerman, interview, Groningen, 26 September 2014). Indeed, SP's discourse is characterized by an inclusionary conception of the popular subject, in terms of equal participation, enjoyment of social welfare and state protection. Simultaneously, its appeals to 'the people' are articulated on the basis of its socioeconomic characteristics. The 'common man', 'the people', refer to the multitude of groups and individuals living within Dutch society, excluding only a small privileged elite of 'capital owners' and 'rich people with high incomes', as SP's secretary general points out (Hans van Heijningen, interview, Amersfoort, 25 September 2014). 'The people' thus emerges as an empty signifier, inclusive enough to fit a vast plurality of subjects and demands beyond ethnicity, religion, etc. Last but not least, socio-political stakes and the 'enemy' of the 'people' are conceptualized within an ideologico-political framework with latent elements of a Marxist analysis ('neoliberal elites/the rich vs. common people/productive forces') and not along moralistic or conspiracy-theory terms; antagonistic camps within society are constructed as being animated by diverging ideologies and political programmes that serve different interests.

\section{Marine Le Pen and the FN in France: The Nation Against Cosmopolitan Globalization}

The FN is largely considered to be the archetype, indeed the cradle of contemporary extreme right-wing populism in Europe. Founded in 1972, after various attempts to unite the French extreme right (Fieschi, 2004, p. 1; Rydgren, 2004, pp. 17-19), it gained momentum under the charismatic leadership of Jean-Marie Le Pen, who had already started a political career within the Poujadist movement (Davies, 1999, p. 3). The FN had its first electoral breakthrough back in 1984 and has managed to establish its position ever since within the French political scene (Shields, 2007, p. 278). After 
the passage from Jean-Marie Le Pen to his daughter, Marine Le Pen, the party continued to rise, achieving a first place in the European election of 2014, which constitutes its best electoral result so far. What was it that made such a trajectory possible? Part of the literature has suggested that this was due to the FN's long but consistent turn towards more moderate positions, the strategy of dédiabolisation, that took place at least at the level of political communication and public presence (Kuhn, 2014, p. 408). On the other hand, according to Aurélien Mondon, beneath the carefully structured 'moderate' profile of Marine Le Pen one finds exactly the same programme on which the $\mathrm{FN}$ has diachronically built its public profile and momentum, stressing anti-immigrant policies, based on nationalism and intolerance (Mondon, 2012).

Now, what have been the basic discursive patterns along which the FN has diachronically built its identity? As we know, one of the first slogans used by the FN was 'France for the French', which in the past had also been used by fascist regimes. Its profile was thus built from the beginning around a notion of national identity, around the French family and French traditional values, while presenting the national community under a constant threat (Davies, 1999, p. 20; Shields, 2007, p. 218). To be sure, the way that the FN constructs the people-as-nation today does not involve racial connotations. It is mostly premised on a kind of differentialist racism, stressing the differences and the incompatibility of certain cultures (mainly Islam) with Western European, and especially French values. The FN is thus referring to the abstract figure of the immigrant as an internal threat to the nation's culture, its integrity, its values. Islam is also openly targeted here (Davies, 1999, pp. 26, 43), but not with the severity seen in Wilders' discourse. An external enemy is also recognized, which is mostly identified with globalization and the forces of cosmopolitanism, that threaten to 
corrode the nation (Davies, 1999, p. 22); especially during the past few years the European Union itself has become one of the arch-enemies of the FN. In this context, the EU is - in Marine Le Pen's words - regarded as 'deeply harmful', or even as 'an anti-democratic monster'. Indeed Le Pen does not hesitate to even state that she wants 'to destroy the EU' on the grounds of regaining popular sovereignty, which is here, importantly, synonymous with national sovereignty (Le Pen, in van Rhor, 2014).

Anti-immigrantism remains until today a central element in understanding FN's discourse, since the broad lines of FN's 'program remain based on a strong antiimmigrant sentiment and exaggerated nationalism', while '[r]ight-wing populism, which made Le Pen senior a serious candidate for two decades, remains central to the politics of the party' (Mondon, 2012). In fact, very recently Marine Le Pen openly stated that her party wants to put an end to immigration. The problem, according to her has to do with the inability of the French economy to bare any more people in a viable way: 'We have millions of unemployed and cannot afford any more immigration. Where are they supposed to live? It is not viable' (Le Pen, in van Rhor, 2014). In addition, as we established through a semi-structured interview with a highly placed official and representative of the FN, the party has started to shift the way in which its anti-immigrant sentiments are presented publicly. The issue now is increasingly that there are vast numbers of immigrants that cannot - or do not want to - become integrated within French society and are thus excluded from the French people on their own responsibility. As the representative of the FN stated:

We maintain that the education system from 1960 onwards has failed to integrate [the immigrants] and to make them comply with the principle of the indivisible nation. [These immigrants] are excluded by themselves. That is why we see the emergence of radical Islamism or other kinds of 
radical communitarianism. [...] We say that we need to be cautious, since there are limits in terms of space and capacity of assimilation and integration. The democratic contract today is in danger due to the massiveness of immigration. We do not have time to integrate them (informant A, interview, Brussels, 14 October 2014, emphasis added).

In this context, the FN today has focused its anti-immigrant rhetoric on the inability of the French state to integrate any more populations, avoiding references to the danger of 'contaminating' the native culture with alien traditions, but also linking it to the democratic process and the dangers that non-integrated immigrants pose for democracy. On another level, the FN has also intensified its attacks on the 'globalized system of banks and super-structures', attacking those that want to establish a system of 'global governance' that cannot be held accountable to the people in a democratic way. It is obvious then that the FN is trying today to articulate the various aspects of its discourse with the contemporary problems of democracy, in an effort to escape its categorization as 'extreme' or 'dangerous'. Thus, when it comes to representing the people, Le Pen's response is that '[w]e want to represent all the French people with ideas that are neither left nor right: patriotism, defence of the identity and sovereignty of the people' (Le Pen, in van Rhor, 2014, our emphasis). At the same time though, Le Pen makes it clear that representing and defending the people ultimately means to represent and defend the nation. This overlapping is obvious when she stresses that: 'The European Union is working to destroy the nation and we are here to defend our people' (Marine Le Pen, in Saeedy, 2015).

To sum up, the FN clearly constructs 'the people' as a subject organically and exclusively linked to the nation. At the same time, it excludes substantial parts of the immigrant populations from the French people in terms of their incomplete 
integration or the very inability of the French state to integrate them due to inflexible limitations (territory, capacity of the economy, etc.). Its interpellation upon the people is structured along an antagonistic logic, on the basis of recognizing an internal and an external enemy: on the inside the enemy is the non-integrated immigrant and the various forms of radicalism that may originate from such parts of the population; on the outside, the enemy is identified with the abstract force of cosmopolitan globalization and the looming threat of 'global governance' (one finds here the 'transnational elites', EU bureaucracy, the US, institutions such as Goldman Sachs, etc.). At the same time though, the FN seems to continuously soften its antiimmigration arguments. In this sense, it seems to move closer to the populist canon and its 'populist' aspect becomes more and more central in opposition to other farright movements and parties. Furthermore, the FN increasingly adopts a traditional conception of 'the people' as political and electoral body, aiming also at the empowerment of its intervention, mostly through referenda, which, nevertheless require the mediation of charismatic leadership, incarnated by Marine Le Pen (informant A, interview, Brussels, 14 October 2014).

Even though the FN seems to have moderated its position, becoming (at least seemingly) less and less 'extreme', by predominantly focusing on external threats to the French nation and on a sharp opposition towards the EU it is led into a rather protectionist-nationalist position. Nevertheless, the fact that the grounding of this positioning is articulated with the call for a renewed popular sovereignty and for institutional changes that would allow for the empowerment of the people regardless of their origin, reveals an increasing importance of certain populist elements. And yet, these elements remain undermined by their nationalist and exclusionist associations, to the extent that, in the final analysis - to use the old motto -, 'popular sovereignty' 
is ultimately reduced to 'national sovereignty' with the French nation operating, once more, as the transcendental signified of the 'people'.

Moving now to the left of the political spectrum in France, we will see that as with the SP and other left-wing populist parties in Europe - the populist political formation Left Front (Front de Gauche / FdG) has, under the leadership of Jean-Luc Mélenchon, identified 'the people' with the vast majority of society, with the lower social strata and dominated social classes and not necessarily or exclusively with the nation. Hence, FdG has clearly included immigrants and foreigners within the (popular) political community it claimed to represent, while it placed emphasis on a participatory model in governance and decision-making. On the other hand, illustrating again elements of a latent Marxist analysis (as in the case of the SP), the FdG opposed French capital while underlining the significance of class struggle. Nevertheless, its now autonomous former leader, Jean-Luc Mélenchon - a leftist politician that has increasingly moved towards the ideal-type of a populist leader recently argued that the old contradiction between capital and labour is overdetermined today by the ultimately dominant clash between the 'people' and the 'oligarchy’ (Mélenchon, 2014), putting forth a very inclusive and quasi-universalist call to 'the people' in which class divisions are underplayed if not diminished. In this sense, 'the people' in Mélenchon's discourse becomes an empty signifier par excellence, defined by its opposition towards an 'oligarchy', which refers to a small privileged elite of political power and money within French society. What this example clearly demonstrates is that when a populist logic prevails, it opens up the signifier 'the people' to a myriad of possible significations and articulations, in opposition to the restrictions a reductive association with the nation tends to produce in right or extreme-right discourses. 


\section{Conclusion}

After surveying, from a discourse-theoretical point of view, parties that are categorized - usually by default - as right or extreme right-wing populist, we can revisit the reified association between the extreme-right and the 'populist' designation. We can thus firstly claim that contemporary research needs to acknowledge the priority of nationalist and xenophobic, anti-immigrant and more generally exclusivist elements in the discourse of these parties. In this sense, Ruth Wodak is correct when she stresses 'the overtly nationalistic orientation of such movements' (Wodak, 2014) and their 'exclusionary agenda' (Wodak, 2015, p. 2); something also registered in recent attempts to distinguish inclusionary from exclusionary types of populism within mainstream political science (see Mudde and Rovira Kaltwasser, 2013). Here a perspective focusing on discursive architectonics as well as on the intricacies of signification can reinforce the conclusions of such orientations offering them an additional grounding.

These discursive and ideological elements, not only delimit this party family, but are often more important as a defining trait than their alleged 'populism'. Populism may still be an element in certain extreme-right parties, but it is clearly not the core discursive/ideological feature on the basis of which one can understand the specificity of their profile, differentially determine their identity and subsequently ascribe the 'populist' label to them as the most fitting and primary designation.

In this context, when examining various discourses, we are mostly concerned with highlighting a specific pattern of articulation, in distinguishing on that basis what is populist from what is not, but also what is less from what is more populist. Similar attempts may be observed in relative research areas, such as fascism studies. Take for example how uncritically a part of this scholarship has tried to introduce 'populism' 
as one of the core characteristics of fascism. To be more specific, Roger Griffin has defined fascism as a 'palingenetic form of populist ultra-nationalism' (Griffin, 2006: 32, 44). John Richardson has eloquently summarized the various critiques against Griffin, but more crucially, he has also stressed that 'it is the anti-democratic weltanschauung and violent methods which set fascism apart from parliamentary right-wing politics' (Richardson, forthcoming). This does not mean that populist elements cannot be found in fascist discourses. The task here, as with our inquiry, has more to do with carefully tracing the core features that define specific parties and movements. Hence, in Richardson's empirical study of the discourse of the British National Party's (BNP) leader, what is stressed is those characteristics that predominantly define the party: ethnic nationalism, anti-international capitalism, reliance on (anti-Semitic) conspiracy theories, its pronounced racism, anti-Marxism, anti-egalitarianism, and finally its targeting of specific social groups within society. On this basis, Richardson approaches BNP within the context of fascist ideology, avoiding the mistake of other researchers who understand BNP in terms of 'A very British populism' (Baggini, 2013).

Coming back to the discursive literature, we have to acknowledge that some significant steps have already been taken in this effort to disentangle populism from the extreme-right and/or from nationalism. For example, in a very recent paper, Benjamin De Cleen has convincingly shown how nationalism and populism play different roles in the discourse of the Belgian Vlaams Blok/Vlaams Belang (VB). Here, radical and exclusionary nationalism is clearly recognized as the ideological core of the party, with populism functioning as a positioning strategy, contingently articulated with nationalism (De Cleen, 2016, p. 87). 
In any case, characteristics like xenophobia, anti-immigrantism, exclusionary (ethnic) nationalism, along with versions of enmity against perceived external threats to the nation, are what clearly differentiates the extreme right from most of the inclusionary, progressive and/or left-leaning versions of contemporary European populism (see Stavrakakis and Katsambekis, 2014; March, 2011). This needs to be taken seriously into account and inform contemporary comparative approaches in a bid to build meaningful typologies: 'Left-wing and right-wing populist parties differ in important aspects, namely in that the latter are inwards looking, thus primarily nationalist/chauvinist, referring to a nativist body politics, while left-wing populist parties are traditionally oriented towards internationalism or post-nationalism' (Wodak, 2015, p. 8).

Our inquiry here offers a first mapping of these characteristics and a critical re-assessment of their alleged populism through the utilization of discursive 'minimal criteria'. The minimum similarities that we discerned among these parties, despite their different versions of nationalism or the different degrees of their alleged populism, can be formulated as follows. Starting from the national-popular side, even when the 'people' acquires a prominent place within an extreme-right discursive ensemble, the nation and the national community, in its different forms, is primarily and almost exclusively understood as the true meaning, the transcendental signified of the 'people'. 'The people' thus acquires an exclusivist character, excluding, in particular, the non-native, the foreigner, or even the non-integrated co-citizen on the basis of preserving a homogenous and indivisible people-as-nation. Hence, the (national) people are called upon to regain 'popular sovereignty' - a stand-in for 'national sovereignty' - by putting their faith in specific leaders and by signing up to new hierarchies. 
Nevertheless, there are still differences in the conception and evaluation of the 'enemy' in the antagonistic positioning of the-people-as-nation. When dealing with extreme and more xenophobic parties, the primary enemy is clearly located in the figure of the invading immigrant that threatens both the native culture and the security of the citizens (islamism, etc.), as in the case of the PVV. For other eurosceptic and extreme right (alleged populist) parties the enemy can be primarily an external threat to the-people-as-nation, usually incarnated by vague figures with dominant economic connotations, like 'global governance', 'Brussels bureaucracy' or the 'New World Order' (as with the FN). In both cases, what seems to prevail in the image of the enemy is some sort of exteriority to both people and nation through which the latter imposes its rationale on the former: even when an 'establishment', a hostile 'power bloc' is identified within the country, it is almost always regarded as the puppet of a broader international formation of power. The solution for the people seems to be the empowerment of charismatic figures (Le Pen, Wilders), totally dominating their parties, that are willing to clash with forces hostile to the nation, fulfilling a mission in quasi-messianic terms. This articulatory profile has led commentators like Pelinka to conclude that 'contemporary populism does not so much mobilize against the (perceived) enemy above but more against the (perceived) enemy from abroad. Populism has become more and more ethno-nationalistic' (Pelinka in Wodak, 2015, p. 4). The crucial question, highlighted by our analysis, is whether it would be more analytically accurate, theoretically and methodologically consistent - as well as strategically more productive - to reconstruct this discursive movement as an attempt to articulate populist elements into discourses that remain, however, predominantly ethno-nationalist and xenophobic. To the extent that, as we have tried to show, the latter can be clearly differentiated from the inclusionary 
populist canon, they should not be primarily designated as 'populist'. With this statement, we are not arguing that right-wing or even extreme-right orientations necessarily exclude populism from the chains of signification they construct. Populism can still be a significant element within such discourses, as illustrated in our argument. But it is crucial to be able to establish if it is the defining element visà-vis others or not. At the same time, it is also crucial for contemporary political research to explore the existence of 'mixed cases,' where nationalist elements are articulated with progressive agendas and participatory discourses with very strong leaderships (as is the case, maybe, with Beppe Grillo's Five Star Movement in Italy).

Finally, what extreme-right framings of socio-political stakes reveal, is an ultimately protectionist (even isolationist) conception of the nation, which refers the people back to the traditional national community and - involving less tolerant views regarding religion, ethnicity or even sexual orientation (this refers to the $\mathrm{FN}$ and not the PVV, which is openly advocating gay rights) - puts restraints on social inclusivity and universal participation in political affairs. In this sense, such discourses can be regarded as potentially harmful to any sense of democratic expansion; a hypothesis that should inform contemporary accounts on the relation of such parties with democracy. Such views, clearly contrast with the inclusive and egalitarian conception of the popular community, which we typically find in populist discourses on the left of the political spectrum, illustrating the variability of popular/populist interpellations.

To be sure, it is the task of contemporary political research to register these developments and to re-asses the terms of categorization applied to such parties by clearly identifying the formal logics implicit in their public appeal. What we offer here is a method to proceed with such categorizations through a discursive 
framework in the Essex School tradition. It is hoped that through such a reassessment we will not only clarify further the peculiarities of populism as such - as well as the role and nature of its presence as a 'secondary strategy' or 'strategic amplifier' of other ideologies, such as nationalism, or the existence of in-between categories of discursive articulation of a national-populist type. We may also arrive at a better position to understand the consequences of today's extreme-right parties on democratic institutions and the prospects for democratic expansion in Europe more generally.

\section{Notes}

1. According to an Essex School perspective, discourse formation involves the partial fixation of a series of signifiers (the moments of a discourse) around a point of reference, a signifier that structures their articulation: this is the operation performed by the nodal point (Howarth, Norval \& Stavrakakis, 2000).

2. This is, of course, Cas Mudde's definition of populism without the rather unnecessary moralistic adjectives (Mudde, 2007).

3. See, for more details: www.populismus.gr

4. Other expert informants that agreed with this assumption were Tjitske Akkerman, Sarah de Lange and Dick Pels.

\section{Acknowledgments}

This paper has been composed within the context of the 'POPULISMUS: Populist Discourse and Democracy' research project (2014-5). POPULISMUS has been implemented at the School of Political Sciences of the Aristotle University of Thessaloniki within the framework of the Operational Program 'Education and 
Lifelong Learning' (Action 'ARISTEIA II') and was co-funded by the European Social Fund (European Union) and Greek national funds (project no. 3217). Many thanks are due to Ioanna Garefi for her technical support.

\section{References}

Akkerman, T. (2005) Anti-immigration Parties and the Defence of Liberal Values: The Exceptional Case of the List Pim Fortuyn. Journal of Political Ideologies 10(3): 337-354.

Anastasakis, O. (2013) Greece's Radical Politics in the Dark Side of the Dawn. EInternational Relations, 5 November, http://www.e-ir.info/2013/11/05/greecesradical-politics-on-the-dark-side-of-dawn/.

Angermuller, J. (2014) Poststructuralist Discourse Analysis. Basingstoke: Palgrave.

Angermuller, J., Maingueneau, D., \& Wodak, R. (eds) (2014) The Discourse Studies Reader. Main Currents in Theory and Analysis. Amsterdam, Philadelphia: John Benjamins.

Baggini, J. (2013) A Very British Populism. Counterpoint.

Caiani, M. and Della Porta, D. (2011) The Elitist Populism of the Extreme Right. Acta Politica 46: 180-202.

Davies, P. (1999) The National Front in France: Ideology, discourse and power. London: Routledge.

De Cleen, B. (2016) The Party of the People Versus the Cultural Elite. Populism and Nationalism in Flemish Radical Right Rhetoric about Artists. JOMEC: Journalism, Media and Cultural Studies Journal 9: 69-91.

de la Torre, C. (ed.) (2015) The Promise and Perils of Populism: Global Perspectives. Lexington Kentucky: University Press of Kentucky. 
Derrida, Jacques (2005) Writing \& Difference. London: Routledge.

Di Tella, T. (1997) Populism into the Twenty First Century. Government and Opposition 32(2): 187-200.

Dutch News (2010) Geert Wilders' PVV is ready to rule on behalf of Henk and $\begin{array}{llll}\text { Ingrid. } & \text { Dutch } & \text { News, } & \end{array}$ http://www.dutchnews.nl/news/archives/2010/04/geert_wilders_pvv_is_ready_t $\underline{\mathrm{o} /}$.

Fieschi, C. (2004) Fascism, Populism and the French Fifth Republic: In the Shadow of Democracy. Manchester: Manchester University Press.

Fortuyn, P. (1997) Tegen de islamisering van onze cultuur: Nederlandse identiteit als fundament. A.W. Bruna.

Griffin, R. (2006) The Nature of Fascism. London: Routledge.

Hainsworth, P. (2008) The Extreme Right in Western Europe. London: Routledge.

Halikiopoulou, D. and Vasilopoulou, S. (2013) The Rise of the Golden Dawn. In: Giusto, H., Kitching, D. and Rizzo, S. (eds) The Changing Faces of Populism. Brussels: Lexington Books, pp. 107-124.

Howarth, D., Norval, A. \& Stavrakakis, Y. (2000) Discourse Theory and Political Analysis. Manchester: Manchester University Press.

Jagers, J. \& Walgrave, S. (2007) Populism as Political Communication Style: An Empirical Study of Political Parties' Discourse in Belgium. European Journal of Political Research 46(3): 319-345.

Katsambekis, G. (2016) Radical Left Populism in Contemporary Greece: Syriza's Trajectory from Minoritarian Opposition to Power. Constellations 23(3): 391403. 
Kuhn, R. (2014) The French Municipal and European Elections, 2014. Representation 50(3): 405-417.

Laclau, E. (1977) Politics and Ideology in Marxist Theory: Capitalism, Fascism, Populism. London: New Left Books.

Laclau, E. (1980) Populist Rupture and Discourse. Screen Education 34: 87-93.

Laclau, E. (2005) On Populist Reason. London: Verso.

Minkenberg, M. (2002) The Radical Right in Postsocialist Central and Eastern Europe. East European Politics and Society 16(2): 335-362.

Moffitt, B. (2016) The Global Rise of Populism. Performance, Political Style, and Representation. California: Stanford University Press.

Mudde, C. (2002) The Pink Populist: Pim Fortuyn for Beginners. e-Extreme 3/2.

Mudde, C. (2007) Populist Radical Right Parties in Europe. Cambridge: Cambridge University Press.

Mudde, C. and Rovira Kaltwasser, C. (eds) (2012) Populism in Europe and the Americas: Threat or Corrective for Democracy?. Cambridge: Cambridge University Press.

Mudde, C. and Rovira Kaltwasser, C. (2013) Exclusionary vs. Inclusionary Populism: Comparing Contemporary Europe and Latin America. Government and Opposition 48(2): 147-174.

Panizza, F. (ed.) (2005), Populism and the Mirror of Democracy. London: Verso.

Phillips, L. \& Jorgensen, M. (2002) Discourse Analysis as Theory and Method. London: Sage.

PVV (2012) Hún Brussel, óns

http://www.pvv.nl/images/stories/verkiezingen2012/VerkiezingsProgramma-

PVV-2012-final-web.pdf. 
Richardson, JE (forthcoming) Fascist Discourse. In Flowerdew, J. \& Richardson, JE (eds) Routledge Handbook of Critical Discourse Studies. London: Routledge.

Rydgren, J. (2004) The Populist Challenge: Political Protest and Ethno-Nationalist Mobilization in France. New York: Berghahn books.

Saeedy, A. (2015) Le Pen, Wilders form New Far-right Bloc in EU Parliament. Reuters, 16 June, http://uk.reuters.com/article/2015/06/16/uk-eu-parliamentidUKKBN0OW1WU20150616.

Shields, J. (2007) The Extreme Right in France from Pétain to Le Pen. London: Routledge.

Stavrakakis, Y. (2003) Religious Populism and Political Culture: The Greek Case. South European Society and Politics 7: 29-52.

Stavrakakis, Y. (2004) Antinomies of Formalism: Laclau's Theory of Populism and the Lessons from Religious Populism in Greece. Journal of Political Ideologies 9(3): 253-267.

Stavrakakis, Y. (2005) Religion and Populism in Contemporary Greece. In: Panizza, F. (ed.) Populism and the Mirror of Democracy. London: Verso, 224-249.

Stavrakakis, Y. \& Katsambekis, G. (2014) Left-wing Populism in the European Periphery: The Case of SYRIZA. Journal of Political Ideologies 19(2): 119142.

Townshend, J. (2003) Discourse Theory and Political Analysis: A New Paradigm from the Essex School?. British Journal of Politics and International Relations 5(1): 129-142.

Townshend, J. (2004) Laclau and Mouffe's Hegemonic Project: The Story So Far. Political Studies 52(2): 269-288. 
van Kessel, S. (2015) Populist Parties in Europe. Agents of Discontent?. Hampshire: Palgrave Macmillan.

van Kessel, S. (2014) While Geert Wilders Suffered a Disappointing Result, the Dutch EP Elections Were Still a Long Way from a 'Vote for Europe'. LSE European Politics and Policy blog, 30 May, http://blogs.lse.ac.uk/europpblog/2014/05/30/while-geert-wilders-suffered-adisappointing-result-the-dutch-ep-elections-were-still-a-long-way-from-a-votefor-europe/.

Voerman, G. (2008) The Disappearance of Communism in the Netherlands. In: Backes, U. \& Moreau, P. (eds) Communist and Post-Communist Parties in Europe, Göttingen: Vandenhoeck \& Ruprecht, pp. 15-38.

von Rohr, M. (2014) Interview with Marine Le Pen: 'I Don't Want this European Soviet Union'. Der Spiegel, 3 June, http://www.spiegel.de/international/europe/interview-with-french-frontnational-leader-marine-le-pen-a-972925.html.

Vossen, K. (2011) Classifying Wilders: The Ideological Development of Geert Wilders and His Party for Freedom. Politics 31(3): 179-189.

Wilders, G. (2008) Speech during the Parliamentary session on the budget for 2009. 17 September, (English translation) http://gatesofvienna.blogspot.gr/2008/09/text-of-geert-wilders-speech-to.html (initial link broken: http://www.pvv.nl/index.php?option=com_content\&task=view\&id=1288\&Itemi $\underline{d=1})$. 
Wilders, G. (2011), The Failure of Multiculturalism and How to Turn the Tide. 25 March, http://www.geertwilders.nl/index.php/77-in-the-press/in-the-press/1740speech-geert-wilders-in-rome-25th-of-march-2011.

Wilders, G. (2014a) Speech during parliamentary debate in the Netherlands. 4 September, $\quad$ http://www.geertwilders.nl/index.php/87-english/news/1872speech-geert-wilders-during-parliamentary-debate-in-the-netherlands.

Wilders, G. (2014b) Speech at the Danish Free Press Society. 2 November, http://www.geertwilders.nl/index.php/94-english/1890-geert-wilders-speechdanish-free-press-society-copenhagen-2-11-2014.

Wodak, Ruth (2014) 'It Would be Dangerous to View Modern European Populism as a Triumph of Style Over http://blogs.lse.ac.uk/europpblog/2014/07/23/it-would-be-dangerous...devoidof-serious-content-or-as-a-triumph-of-style-over-substance/

Wodak, Ruth (2015) The Politics of Fear: What Right-Wing Populist Discourses Mean. London: Sage. 